\title{
DEMAND ANALYSIS FOR STRATEGIC FOOD IN INDONESIA DURING ECONOMIC CRISIS AND ITS IMPLICATION ON FOOD CONSUMPTION AMONG HOUSEHOLDS WITH CHILDREN UNDER TWO YEARS
}

\author{
Anna Vipta Resti Mauludyani, Umi Fahmida, Otte Santika \\ South East Asian Ministries of Education Organization, Regional Center for Food and Nutrition, \\ University of Indonesia \\ vipta11@yahoo.com
}

\begin{abstract}
The objective of the study is to analyze demand elasticity for strategic foods during economic crisis and its implication on food and nutrient consumption among household in Indonesia. This ecological study was conducted to 14,767 households owned children less than two years included in National Socioeconomic Survey 2007. Analysis was conducted by using econometric model of Double-Log Regression in SAS program. Result of analysis showed that the own-price elasticities were all found to be negative as expected, meaning that increased price of strategic food tended to reduce its demand. In conclusion, the effect of food crisis was visible to most of the strategic foods which their demand tended to be highly affected by price changes. This effect was mostly seen in rural and low income households which had limited income to purchase food. Improved income tended to increase demand of strategic foods. Demand on protein sources were highly affected by income changes.
\end{abstract}

Keywords: demand analysis, strategic food, food consumption, nutrient intake.

\section{ABSTRAK}

\section{ANALISIS PERMINTAAN PANGAN STRATEGIS DI INDONESIA PADA MASA KRISIS EKONOMI DAN IMPLIKASINYA TERHADAP KONSUMSI PANGAN PADA RUMAH TANGGA DENGAN ANAK BADUTA}

Penelitian ini bertujuan untuk menganalisis elastisitas permintaan pangan strategis dan implikasinya terhadap konsumsi pangan dan gizi rumah tangga di Indonesia. Penelitian dengan desain ecological study ini dilakukan terhadap 14.767 rumah tangga yang memiliki anak berusia di bawah dua tahun (baduta) yang tercakup dalam Survei Sosial-Ekonomi Nasional 2007. Analisis dilakukan menggunakan model ekonometrika Regresi Log-Ganda dengan software SAS. Hasil analisis menunjukkan bahwa elastisitas harga seluruh jenis pangan strategis, sebagaimana diharapkan, bernilai negatif yang berarti kenaikan harga pangan tersebut akan menurunkan permintaannya. Sebagai kesimpulan, pengaruh krisis pangan akan terlihat pada permintaan makanan strategis yang dipengaruhi oleh perubahan harga. Pengaruh sangat terlihat pada pedesaan dan keluarga berpendapatan rendah yang mempunyai keterbatasan dalam membeli makanan. Peningkatan pendapatan cenderung meningkatkan permintaan pangan strategis. Permintaan akan makanan sumber protein sangat dipengaruhi oleh perubahan pendapatan.

Kata kunci: analisis permintaan, pangan strategis, konsumsi pangan, asupan gizi

\section{INTRODUCTION}

G lobal economic crisis as the combination of food, fuel, and financial crisis in 20072008 caused increase in global food price. In last 5 years, increase in fuel price caused increase in price of commodities which were potential to be energy sources (bioethanol) which were sugar, corn, cassava, soybean, and palm oil. ${ }^{1}$ Climate change, as the impact of global warming, also contributed to reduced agricultural production, especially food production. ${ }^{2}$ The crisis was worse when global financial crisis happened which had effect on increased global food price, especially in producer countries. ${ }^{3}$ In term of consumption, this food crisis and high food price was caused by increased food demand as the impact of rapid population growth. ${ }^{4}$ The rate of price index of wheat, corn, and rice was increased from $16.7 \%$ in 2006 became $50.6 \%$ in $2008 . .^{5}$ Moreover, between 2000 and its peak in 2008, the FAO cereal price index was more than tripled. ${ }^{6}$ 
The food price increase can have direct effect on food security or on insufficient utilization, availability, and accessibility to adequate and safe diets. ${ }^{7}$ Households have reduced the quantity and quality of food consumed in the face of higher food price. Households reduce energy intake in response to increase food price and reduce income. The pathway is by reducing the size and frequency of meals in their consumption. When households reduce the size and number of meals, they will likely suffer deficiencies in macronutrients, including energy and protein. ${ }^{6}$

Analysis of food can be conducted to several foods considered as strategic foods. Conducting analysis to all food is not feasible due to large number of food consumed by people. Since this study is focusing on food analysis related to under two years old children, food analyzed should be also added with food usually consumed by children under-two. The food also should have high energy and protein contribution to people's food consumption. Moreover, Ministry of Agriculture (MOA) also stated some strategic foods regulated by government. ${ }^{3}$

The National Socio-Economic Survey (Susenas) is potential data source to analyze food and nutrition. Susenas is annual household survey made to collect socioeconomic data widely in national scope conducted by Central Bureau of Statictics (BPS). ${ }^{8}$ The survey involves large numbers of samples with national scope, include hundreds of variables, have good methodology, and use billions of budgets. Therefore, using Susenas data are optimizing available and accessible resource.

Study on demand analysis during economic crisis using national data is still limited, especially in Indonesia. Therefore, this study is important to be conducted.

\section{MATERIALS AND METHODS}

The data used in this analysis were collected from nationally representative survey, which were National Socioeconomic Survey (Susenas) year 2007. Susenas is household survey made to collect socioeconomic data widely in national scope. The sampling of Susenas was multistage cluster sampling. It is charged with a mission to gather socio- economic data among others, concerning education, demography, health/nutrition., housing/environment, criminality, socio-culture activities, household consumption/expenditure, domestic travel, and community opinion regarding their own welfare. The data collection was conducted in February-March 2007. The Susenas collected data on two groups of consumption, i.e. food and non-food consumption. There are 215 items of household food consumption appeared in the questionnaire in terms of quantities and values. For non-food consumption items, which consists of 104 items, only data on value were collected, except for some consumption items such as electricity, water, fuel, and charcoal. The interview was conducted to head of household or other household member who is familiar with the household's affairs. Total household in Core Susenas 2007 was 274,184. Number of household included in Module Susenas 2007 was 64,880 . This study analyzed 14,767 households having children less than two years included in Susenas 2007.

All data have been collated from secondary source of the Central Bureau of Statistics (BPS), which were Susenas year 2007. Total monthly household $(\mathrm{HH})$, food, and strategic food expenditure in Rp/cap/mo and food price in Rp were obtained from Susenas. Strategic foods in this study were rice, corn, cassava, sweet potatoes, wheat flour, soybean, beef, egg, chicken, milk, fish, sugar, cooking oil, formula milk, and manufactured complementary food (CF).

Before entered into empirical model, price of each strategic food needed to be formulated based on price of all food details. The price of certain food was obtained through calculation of weighed price of all forms of food. As example, price of rice was obtained by calculating weighed price of rice, glutinous rice, rice meal, and rice noodle. The weighing was based on consumption of each food details.

In order to get price and income elasticity, econometric model, namely Double-Log Regression (DLR) was used. In DLR, coefficient $\beta$ predicts elasticity of $Y$ for $X$, which is percentage of change in $Y$ due to certain percentage of change in $X$. Therefore, $\beta$ is called coefficient of elasticity. In Calculus, coefficient of elasticity is defined as $(d Y / Y) /(d X / X)=(d Y / d X)(X / Y)(9)$. The empirical 
models used in this study were mentioned below:

$\operatorname{Ln} Y_{1-5,14-15}=a+\beta_{1} \operatorname{Ln} X_{1}+\beta_{2} \operatorname{Ln} X_{2}+\beta_{3} \operatorname{Ln} X_{3}+\beta_{4} \operatorname{Ln} X_{4}+\beta_{5} \operatorname{Ln} X_{5}+\beta_{14} \operatorname{Ln} X_{14}+\beta_{15} \operatorname{Ln} X_{15}+\gamma \operatorname{LnP}+e \ldots(1)$

$Y_{1} \quad=$ Demand of rice;

$Y_{2} \quad=$ Demand of corn;

$\mathrm{Y}_{3} \quad$ = Demand of cassava;

$Y_{4} \quad$ = Demand of sweet potatoes;

$Y_{5} \quad=$ Demand of wheat flour;

$\mathrm{Y}_{14} \quad$ = Demand of formula milk;

$\mathrm{Y}_{15} \quad=$ Demand of manufactured CF;

$P \quad=$ Income

$\mathrm{X}_{1} \quad=$ Price of rice;

$\mathrm{X}_{2} \quad=$ Price of corn;

$\mathrm{X}_{3} \quad=$ Price of cassava;

$X_{4} \quad=$ Price of sweet potatoes;

$X_{5} \quad=$ Price of wheat flour;

$X_{14} \quad=$ Price of formula milk;

$\operatorname{Ln} Y_{6-11}=\alpha+\beta_{6} \operatorname{Ln} X_{6}+\beta_{7} \operatorname{Ln} X_{7}+\beta_{8} \operatorname{Ln} X_{8}+\beta_{9} \operatorname{Ln} X_{9}+\beta_{10} \operatorname{Ln} X_{10}+\beta_{11} \operatorname{Ln} X_{11}+\gamma \operatorname{Ln} P+e \ldots(2)$

$Y_{6} \quad$ = Demand of soybean;

$Y_{7} \quad=$ Demand of beef;

$Y_{8} \quad$ = Demand of egg;

$Y_{9} \quad=$ Demand of chicken;

$\mathrm{Y}_{10} \quad=$ Demand of milk;

$Y_{11} \quad=$ Demand of fish;

$\mathrm{P} \quad=$ Income

$\operatorname{Ln} Y_{12}=a+\beta_{121} \operatorname{Ln} X_{121}+\gamma L n P+e \ldots(3)$

$Y_{12}=$ Demand of sugar;

$\mathrm{P} \quad=$ Income

$\operatorname{Ln} Y_{13}=a+\beta_{131} \operatorname{Ln} X_{131}+\gamma L n P+e \ldots(4)$

$Y_{13} \quad=$ Demand of cooking oil;

$\mathrm{P} \quad=$ Income

Statistical analysis was carried out using SAS version 9. Econometric model of doublelog regression were used to analyze demand elasticity of strategic food. P-value $<0.05$ was considered significant.

The result of analysis was presented based on region (urban+rural, urban, and rural) and income class (low $/ 40 \%$ lowest income, medium $/ 40 \%$ higher income, and high $/ 20 \%$ highest income). This study was conducted after receiving permission from Indonesian Center for Agriculture Socio Economic and Policy Studies (ICASEPS), Ministry of Agriculture, to use Susenas data at the year 2007.
$X_{6} \quad=$ Price of soybean;

$X_{7} \quad=$ Price of beef;

$X_{8} \quad=$ Price of egg;

$X_{9} \quad=$ Price of chicken;

$X_{10}=$ Price of milk;

$X_{11}=$ Price of fish;

$\mathrm{X}_{121}=$ Price of sugar;

$X_{131} \quad=$ Price of cooking oil;

\section{RESULTS}

The own-price elasticities of strategic foods were all found to be negative as expected. The meaning of this was that higher price of strategic food tended to reduce its demand. Overall, elastic value was found in 10 of 15 of the strategic foods, which were rice, corn, cassava, wheat flour, soybean, egg, chicken, milk, fish, and sugar.

Overall, the reduction of demand in response to strategic food price increase was higher in rural than in urban. 
Among income class, low income household tended to reduce the demand of strategic food, namely rice, corn, cassava, wheat flour, soybean, egg, fish, sugar, and cooking oil. High income household tended to reduce beef consumption in large proportion (Table 1).

Table 1

Own-Price Elasticity of Strategic Foods

\begin{tabular}{|c|c|c|c|c|c|c|}
\hline \multirow{2}{*}{ Food } & \multicolumn{3}{|c|}{ Region } & \multicolumn{3}{|c|}{ Income Class } \\
\hline & Urban+Rural & Urban & Rural & Low & Medium & High \\
\hline Rice & $-1.78^{* *}$ & $-0.25^{*}$ & $-2.47^{* *}$ & $-2.97^{\star \star}$ & $-0.61^{* *}$ & $-1.13^{* *}$ \\
\hline Corn & $-1.12^{\star *}$ & $-0.53^{* *}$ & $-1.48^{* *}$ & $-1.93^{* *}$ & $-0.75^{\star *}$ & $-0.28^{*}$ \\
\hline Cassava & $-1.13^{* *}$ & -0.09 & $-1.48^{* *}$ & $-1.54^{* *}$ & $-1.06^{* *}$ & -0.05 \\
\hline Sweet potatoes & $-0.74^{\star *}$ & $-0.46^{*}$ & $-0.86^{\star *}$ & $-0.61^{\star *}$ & $-0.90^{\star *}$ & $-0.59^{*}$ \\
\hline Wheat flour & $-1.49^{\star *}$ & $-1.14^{\star *}$ & $-1.62^{* *}$ & $-2.45^{\star \star}$ & $-0.96^{* *}$ & $-0.65^{*}$ \\
\hline Soybean & $-2.24^{\star *}$ & $-1.67^{* *}$ & $-2.40^{* *}$ & $-2.67^{\star *}$ & $-2.00^{* *}$ & $-1.14^{\star *}$ \\
\hline Beef & $-0.89^{* *}$ & $-0.95^{\star *}$ & $-0.65^{\star *}$ & $-0.47^{* *}$ & $-0.94^{* *}$ & $-1.12^{*}$ \\
\hline Egg & $-2.01^{* *}$ & $-1.34^{* *}$ & $-2.09^{* *}$ & $-2.32^{\star *}$ & $-2.03^{* *}$ & $-1.02^{* *}$ \\
\hline Chicken & $-2.27^{\star *}$ & $-3.02^{* *}$ & $-1.68^{* *}$ & $-1.13^{* *}$ & $-3.14^{* *}$ & $-2.62^{* *}$ \\
\hline Milk & $-1.81^{* *}$ & $-2.11^{* *}$ & $-1.69^{* *}$ & $-1.36^{\star *}$ & $-2.57^{* *}$ & $-1.43^{* *}$ \\
\hline Fish & $-1.04^{\star *}$ & $-0.44^{* *}$ & $-1.26^{\star \star}$ & $-1.59^{\star *}$ & $-0.66^{\star *}$ & $-0.26^{*}$ \\
\hline Sugar & $-1.40^{\star *}$ & $-0.86^{\star *}$ & $-1.67^{\star *}$ & $-2.02^{\star *}$ & $-0.94^{\star *}$ & $-0.82^{\star *}$ \\
\hline Cooking oil & $-0.93^{\star *}$ & $-0.39^{* *}$ & $-1.26^{\star *}$ & $-1.26^{\star \star}$ & $-0.77^{\star *}$ & $-0.40^{*}$ \\
\hline Formula milk & $-0.63^{\star *}$ & $-0.61^{* *}$ & $-0.94^{* *}$ & $-0.60^{* *}$ & $-1.00^{* *}$ & 0.21 \\
\hline Manufactured CF & $-0.29^{* *}$ & $-0.49^{* *}$ & $-0.14^{* *}$ & $-0.25^{\star \star}$ & $-0.41^{* *}$ & -0.15 \\
\hline
\end{tabular}

Most of strategic foods tends to have increased demand as response to have improved income. However, this study found that demand of corn and cassava was lowered as income improved. There were 8 out of 15 strategic foods, especially protein sources, whose demand increased elastically as response to higher income. Rural and low income household tended to have elastic demand increase on rice, wheat flour, soybean, egg, fish, and cooking oil as the response of higher income. Beef, formula milk, and manufactured CF were preferred by urban and high income households, while chicken and milk were preferred by urban and medium income households (Table 2). 
Table 2

Income Elasticity of the Strategic Foods

\begin{tabular}{|c|c|c|c|c|c|c|}
\hline \multirow{2}{*}{ Food } & \multicolumn{3}{|c|}{ Region } & \multicolumn{3}{|c|}{ Income Class } \\
\hline & Urban+Rural & Urban & Rural & Low & Medium & High \\
\hline Rice & $0.31^{* \star}$ & $-0.06^{*}$ & $0.59^{\star \star}$ & $1.43^{* \star}$ & 0.02 & -0.12 \\
\hline Corn & $-0.85^{\star *}$ & -0.03 & $-1.32^{\star *}$ & $-3.12^{* *}$ & -0.29 & 0.25 \\
\hline Cassava & $-0.92^{* *}$ & $-0.81^{* *}$ & $-0.63^{* *}$ & -0.40 & $-1.40^{* *}$ & $-0.97^{* *}$ \\
\hline Sweet potatoes & -0.07 & 0.03 & 0.06 & 0.09 & 0.21 & -0.11 \\
\hline Wheat flour & $1.94^{* *}$ & $0.94^{* *}$ & $2.54^{* *}$ & $4.34^{* *}$ & $1.63^{\star *}$ & 0.12 \\
\hline Soybean & $1.77^{\star *}$ & $0.69^{* *}$ & $2.12^{* *}$ & $3.05^{\star *}$ & $1.53^{* *}$ & $0.48^{*}$ \\
\hline Beef & $1.00^{* *}$ & $1.39^{* *}$ & $0.47^{* *}$ & $0.25^{\star *}$ & $1.05^{\star *}$ & $1.98^{* *}$ \\
\hline Egg & $2.17^{* *}$ & $1.11^{* *}$ & $2.70^{* *}$ & $4.16^{* *}$ & $1.57^{* *}$ & 0.18 \\
\hline Chicken & $2.83^{* *}$ & $2.82^{* *}$ & $2.40^{* *}$ & $2.58^{* *}$ & $3.67^{* *}$ & $1.18^{* *}$ \\
\hline Milk & $2.52^{* *}$ & $2.28^{* *}$ & $2.29^{* *}$ & $2.11^{* *}$ & $3.32^{* *}$ & $1.44^{* *}$ \\
\hline Fish & $1.27^{* *}$ & $0.83^{* *}$ & $1.63^{\star *}$ & $2.32^{* *}$ & $1.04^{\star *}$ & 0.25 \\
\hline Sugar & $0.94^{* *}$ & $0.54^{* *}$ & $1.33^{* *}$ & $2.27^{* *}$ & $0.66^{* *}$ & $-0.17^{*}$ \\
\hline Cooking oil & $0.57^{\star *}$ & $0.32^{* *}$ & $0.80^{* *}$ & $1.35^{* *}$ & $0.29^{*}$ & -0.07 \\
\hline Formula milk & $2.68^{* *}$ & $2.81^{* *}$ & $2.04^{\star *}$ & $1.41^{* *}$ & $3.55^{\star *}$ & $2.44^{* *}$ \\
\hline Manufactured CF & $0.49^{* *}$ & $0.54^{* *}$ & $0.39^{* *}$ & $0.25^{*}$ & $0.49^{*}$ & $0.51^{*}$ \\
\hline
\end{tabular}

\section{DISCUSSION}

Elastic value of own-price elasticity was found in most of the strategic foods. This showed that the 2007 food crisis caused reduction in real income of household. ${ }^{5}$ The reduction of demand as response to increased strategic food price was higher in rural than in urban. This was because income of households in rural was lower than in urban. With limited income, rural income household easily reduce the demand in response to increased strategic food price even if the food was usually consumed by them. ${ }^{10}$ As a response to an increased price, strategic food consumption was decreased to a greater extend among low income households.

Staple foods, except sweet potatoes, tend to be highly affected by high price. On the other hand, based on Susenas 2005, staple food, especially rice, cassava, and sweet potatoes was inelastic. ${ }^{11}$ This showed that the 2007 food crisis tended to reduce the demand in large proportion which further increases risk of inadequate intake of energy.

The risk of inadequate energy intake was more likely to happen in rural and low income households. Rural household with lower income tended to reduce the consumption of staple food in response to high food price. However, this pattern was not seen in wheat flour. This food, which was relatively high in price, was consumed more by urban and high income household. Therefore, rural and low income household tend to easily reduce the consumption of wheat flour as well as rice consumption. Consumption of wheat flour in the form of noodle as side dish of rice was likely to be the reason, making rice and noodle complementary goods to each other. Even though, in general, sweet potatoes was inelastic, rural and low income household tend to replace it with rice as staple food in response to high price of sweet potatoes and limited income. Rice was still the main staple food for Indonesian people as it is consumed by almost all household and had high energy contribution to people's consumption. Rice was chosen as staple food because the taste is good, fast and practical to serve, had relatively better nutrient content, and had high social status. ${ }^{12}$

Protein sources, except beef, tended to be highly affected by higher price. The effect was relatively higher than in 2002 and 2005.11,13 This proved that the 2007 food crisis tended to reduce the demand in large proportion which 
further increases risk of inadequate intake of protein.

Soybean, egg, and fish consumption were highly affected by high price in urban and low income household. Soybean, egg, and fish were consumed more by urban household. Therefore, high price tended to make the household reduce the consumption. On the other hand, low income household, which usually do not consume these foods, tended to easily reduce the consumption in response to higher price. Low income household only had ability to purchase staple food since the price of protein source was relatively high. In response to higher price, low income household tended to reduce beef consumption in large proportion. This was because this food was highly consumed by household with high income. Beef is considered as luxurious food with high social status. This food is relatively expensive so that only household with relatively high income could afford. ${ }^{14}$ Chicken and milk were elastic in urban and medium income households since they were consumed more by urban and medium income households. High price of chicken and milk tended to make the household reduce the consumption.

Protein sources was potential to replace each other. However, this potential was limited. In response to higher soybean or fish price, rural and low income household tended to have beef as protein source. This was not in line with reality. Rural and low income households possibly cannot afford beef due to its expensive price. Thus, high price of a protein sources tended to increase the risk of inadequate intake of protein.

Formula milk and manufactured CF were not highly affected by high price, possibly because their consumption was very low. Sugar and cooking oil tended to be highly affected by higher price. Data in 2002 and 2005 showed the inelastic value of these foods. ${ }^{11,13}$ This showed that the 2007 food crisis tended to elastically reduce the demand of sugar and cooking oil which further increases risk of inadequate energy intake since these food contained high energy. Sugar and cooking oil were elastic in rural and low income household. Rural and low income households with limited income only have ability to purchase staple foods. Therefore, consumption of sugar and cooking oil can be easily reduced. Food which contained sugar would be less sweet as the response of higher price. ${ }^{13}$ Cooking oil was also used for several times in order to save money.

Most of strategic foods were normal goods which their consumption tended to be increased as income improved. However, consumption of corn and cassava tended to decrease as income increased. This showed that these foods were still considered as inferior foods for common people.

Wheat flour, protein sources, and formula milk tended to be highly increased in response to improved income. Data from 2002 and 2005 showed inelasticity of these strategic food. ${ }^{11,13}$ This proved that in the condition of food crisis, consumption of these foods tended to increase in large proportion even by little income improvement. Thus, higher income was potential to improve energy and protein intakes. Overall, rural and low income household tended to increase the consumption more than other household.

Wheat flour consumption tended to be highly affected by higher income in rural and low income household. This food, which was relatively high in price, was consumed more by urban and high income household. Therefore, rural and low income household tended to consume wheat flour which was considered as food with high social status and therefore improved energy intake. In low income household, increase in income also tended to increase rice consumption which further improved energy intake.

Soybean, egg, and fish consumption were highly affected by increased income in rural and low income household. Rural and low income households which usually did not consume these foods tended to easily increase the consumption in response to higher income. In response to higher income, urban and high income households tended to increase beef consumption in large proportion. This was because this food was usually consumed by these households. Chicken and milk were elastic in urban and medium income households since they were consumed more by these households. Higher income tended to make the household increase the consumption. As the conclusion, increased income tended to improve protein intake.

Formula milk was highly affected by increased income in urban and medium income 
household. This was because formula milk was usually consumed by these households. Further, this was potential to improve energy and protein intake. Overall, sugar and cooking oil tended to be highly affected by increased income in rural and low income household. These foods were usually consumed by these households. However, this increase is potential to increase risk of degenerative disease in rural and low income household.

This study proved the hypothesis that strategic foods are highly affected by price and income changes. While most of strategic food was highly influenced by price change, only strategic foods which were protein sources were highly affected by income changes. The strategic foods which were highly affected by price changes were not always highly affected by income changes. This was because the demand of particular food did not only depend on price and income, but also on household size age, preference, geographical condition, knowledge on health and nutrition, and food characteristics. ${ }^{15}$

\section{CONCLUSIONS}

The effect of food crisis was visible to most of the strategic foods that their demand tended to be highly affected by price changes. This effect was mostly seen in rural and low income household which had limited income to purchase food. Higher income households tended to increase demand of strategic food. However, this was not seen in corn and cassava which were still considered as inferior food. Protein sources were highly affected by income changes.

\section{RECOMMENDATIONS}

This study recommends that to overcome negative effect of economic crisis, in short term, supports on food aid and agricultural input are needed for vulnerable group especially in rural and low income household. In long term, price stability of strategic food, especially fortified food, also should be enhanced.

\section{REFERENCES}

1. Arifin B. Bioenergi: Status Saat ini dan Perspektif ke Depan. Dalam: Seminar
Nasional Era Baru Pembangunan Pertanian: Strategi Mengatasi Masalah Pangan, Bio-energi dan Perubahan Iklim, 25 November 2010, Bogor:. Pusat Sosial Ekonomi dan Kebijakan Pertanian, Kementerian Pertanian, 2010.

2. Husen S. Prospek, Kendala, dan Kebijakan Investasi di Sektor Pertanian: Pandangan Pelaku Usaha. Seminar Nasional Era Baru Pembangunan Pertanian: Strategi Mengatasi Masalah Pangan, Bio-energi dan Perubahan Iklim, 25 November 2010, Bogor: Pusat Sosial Ekonomi dan Kebijakan Pertanian, Kementerian Pertanian, 2010

3. Kementerian Pertanian. Rancangan rencana strategis kementerian pertanian tahun 2010-2014. Jakarta: Kementerian Pertanian; 2009.

4. Evan A. The feeding of the nine billion: global food security for the $21^{\text {st }}$ century. Rome: WFP; 2009 (cited 2009 Jan 22). Available from: http://beta.wfp.org.

5. Rusastra IW, Saliem HP, Ashari. Krisis Global Pangan-Energi-Finansial: Dampak dan Respon Kebijakan . Analisis Kebijakan Pertanian. 2010; 8(1):29-48

6. Brinkman H-J, de Pee S, Sanogo L, Subran $L$, Bloem MW. High food prices and the global financial crisis have reduced access to nutritious food and worsened nutritional status and health. J Nutr. 2010;140:153-61.

7. Darnton-Hill I, Cogill B.. Maternal and young child nutrition adversely affected by external shocks such as increasing global food prices. J Nutr. 2010;140:162S-9S.

8. Biro Pusat Statistik. Pengeluaran untuk Konsumsi Penduduk Indonesia 2006. Jakarta: BPS, 2006.

9. Johnston, J. Econometric Methods. International Student Edition. New York: McGraw-Hill; 1972.

10. Ariani M, Saliem HP, Hastuti S, Wahida, Sawit MH. Dampak Krisis Ekonomi Terhadap Konsumsi Pangan Rumah Tangga. Bogor: Pusat Penelitian Sosial Ekonomi Pertanian, Badan Penelitian dan Pengembangan Pertanian, Departemen Pertanian; 2000.

11. Mauludyani, AVR. Elastisitas permintaan pangan strategis berdasar analisis data 
Susenas 2005 dan implikasinya terhadap konsumsi dan upaya perbaikan konsumsi pangan masyarakat Indonesia. Skripsi. Bogor: Fakultas Pertanian, Institut Pertanian Bogor, 2008.

12. Martianto $D$, Ariani $M$. Analisis perubahan konsumsi dan pola konsumsi pangan masyarakat dalam dekade terakhir. Dalam: Prosiding Widyakarya Nasional Pangan dan Gizi VIII. Jakarta: LIPI; 2004.

13. Harianto, Fariayanti A, Saliem HP, Suryani $\mathrm{E}$, Ariningsih $\mathrm{E}$, Rosiana N, Jahroh $\mathrm{S}$. Karakteristik dan Arah Perubahan Konsumsi dan Pengeluaran Rumah
Tangga. Laporan Penelitian. Bogor: Pusat Analisis Sosial Ekonomi dan Kebijakan Pertanian, Kementerian Pertanian; 2008.

14. Martianto D. Konsumsi dan Permintaan Pangan Hewani di Berbagai Propinsi di Indonesia. Tesis. Bogor: Sekolah Pascasarjana, Institut Pertanian Bogor, 1995.

15. Azahari, DH. Kajian permintaan minyak goreng pada berbagai golongan pendapatan dan segmen pasar di Indonesia. Bogor: Forum Penelitian Agro Ekonomi, 1984. 